\title{
Receiving, Handling, Storage, Thawing, Distribution, and Administration of CAR-T Cells Shipped from the Manufacturing Facility
}

\author{
Catherine Rioufol and Christian Wichmann
}

\section{Definition}

In the manufacturing process for antigen receptor $\mathrm{T}$ cell (CAR-T cell) therapies, the patient's T cells acquire medicinal product status after enrichment, genetic modification, and expansion.

This pharmacologic effect results from insertion of a transgene coding for CAR, recognizing the tumour antigen, lysing the tumour cells, and activating the immune system see Chaps. 1, 2 and 3 in Section 1. Moreover, CAR-T cells massively expand upon interaction with antigen-positive cells within the blood system, thereby increasing the number of administered ATMP cells to high numbers (June et al. 2018). Due to this pharmacologic mechanism, CAR-T cells, despite their cellular nature, are gene therapy medicinal products. Whether from patients or healthy donors, CAR-T cells belong to the class of advanced therapy medicinal products (ATMPs), as defined in Regulation EC N¹394/2007 of the European Parliament and in Directive 2009/120/EC of the Council of November 13, 2007 on ATMPs, amending Directive 2001/83/EC and Regulation $N^{\circ} 726 / 2004$.

As a consequence of this medicinal status, CAR-T cells fall under the responsibility of the hospital pharmacist. The manufacturer ships the released drugs to the pharmacy of the treatment centre; the hospital pharmacist is responsible of each step: reception, handling, storage, thawing, and dispensation (Pinturaud et al. 2018), regardless of whether the CAR-T cells are on the market or being used experimentally in a clinical trial. In hospitals with a Cell Processing Facility, the pharmacy

\author{
C. Rioufol $(\bowtie)$ \\ Hospices Civils de Lyon, UCBL1, EA 3738 CICLY, Lyon, France \\ e-mail: catherine.rioufol@chu-lyon.fr \\ C. Wichmann \\ Department of Transfusion Medicine, Cell Therapeutics and Hemostaseology, University \\ Hospital, LMU Munich, Munich, Germany \\ e-mail: Christian.Wichmann@med.uni-muenchen.de
}


may elect to subcontract certain technical operations to the Cell Processing Facility, as defined in an internal agreement. The overall handling and working process must be compliant with legal requirements enforced by local and national health authorities, and with the technical requirements of the drug-producing company (checked through audits and training courses).

\begin{tabular}{|c|c|}
\hline$N$ & Description of the process \\
\hline & $\begin{array}{l}\text { - Handling of CAR-T cells according to ATMP requirements, ensuring } \\
\text { product safety and health care worker protection. Personal protective } \\
\text { equipment (PPE) to protect the handling team involved throughout the } \\
\text { various stages of the 'CAR-T pathway' } \\
\text { - 'CAR-T hospital pathway' is supervised by the pharmacist; the steps are } \\
\text { defined by the pharmaceutical team in coordination with the medical and } \\
\text { nursing teams of the Haematology Department to meet objectives and ease } \\
\text { the patient's care pathway } \\
\text { - Need of a reliable adapted quality assurance system with initial and } \\
\text { continuous training programs for all those involved, and periodic } \\
\text { assessment, in addition to the centre qualification by the pharmaceutical } \\
\text { laboratories } \\
\text { - At many centres, CAR-T cell products are managed by specialized } \\
\text { oncology pharmaceutical teams involved in cancer patient monitoring and } \\
\text { treatment, and in close contact with the oncology department } \\
\text { - Staff training and on-site inspection conducted by the manufacturer } \\
-\quad \text { Process control through web-based communication tools, with access } \\
\text { provided by the manufacturer }\end{array}$ \\
\hline $\begin{array}{l}\text { Reception and } \\
\text { conformity } \\
\text { check }\end{array}$ & 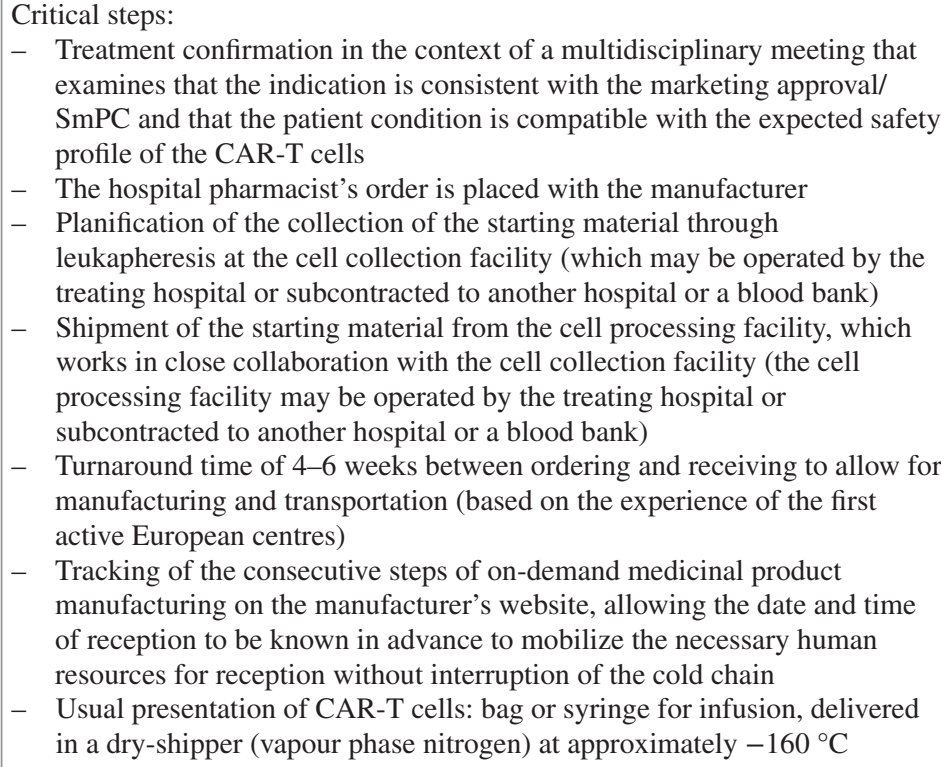 \\
\hline
\end{tabular}




\begin{tabular}{|c|c|}
\hline Workflow & Description of the process \\
\hline & $\begin{array}{l}\text { - Reception of the dry-shipper in ventilated premises } \\
\text { - Conformity check at reception with reception documents (travel } \\
\text { documents, certificates of analysis and release, temperature logs, labels): } \\
\text { Cryo-shipper check: no visible damage and/or leaks } \\
\text { Opening of the metal cassette to fully inspect the frozen cell product } \\
\text { Checking the completeness and accuracy of information printed on the } \\
\text { CAR-T cell label: patient identity and drug identity. Proper labelling is key } \\
\text { to maintain the Chain of Identity/Chain of Custody throughout the } \\
\text { manufacturing process, up to administration of the medicinal product to } \\
\text { the intended recipient } \\
\text { - Back-up bag: whether a back-up bag is available at the manufacturer's site } \\
\text { should be systematically stated in the reception documents. In case of } \\
\text { nonconformity detected at reception, this information is very useful for the } \\
\text { pharmacist and haematologists in determining the treatment strategy: a } \\
\text { back-up bag enables timely administration within } 48 \mathrm{~h} \text { via replacement of } \\
\text { the defective CAR-T cells } \\
\text { - All retrieved information is entered on the manufacturer's website } \\
\text { - Transfer of the CAR-T cells to a cryogenic recipient } \\
\text { - Management of out-of-range temperature or other abnormalities: storage } \\
\text { of CAR-T cells in quarantine and contact of the manufacturer for } \\
\text { instructions } \\
\text { - Final check of Out of Specifications (OOS) } \\
\text { Double control involving two members of the pharmacy team or one } \\
\text { member each from the pharmacy and cell processing facility for reception, } \\
\text { conformity checking, and transfer to the cryogenic recipient }\end{array}$ \\
\hline $\begin{array}{l}\text { Storage } \\
\begin{array}{|cc}7 & 14.007 \\
\mathbf{N}\end{array}\end{array}$ & $\begin{array}{l}\text { - Storage in vapour phase nitrogen tanks. In hospitals with a cell processing } \\
\text { facility, storage is possible in a dedicated nitrogen tank. Respective } \\
\text { responsibilities are then defined in an agreement approved by the health } \\
\text { authority } \\
\text { - } \\
\text { The cryogenic premises preferably contain several nitrogen tanks for } \\
\text { back-up in case of dysfunction. Having several distinct tanks also allows } \\
\text { CAR-T cells with market authorization to be distinguished from those } \\
\text { used in clinical trials or from other ATMPs. The tanks are fed by a central } \\
\text { filling tank, and filling should be automated and levels monitored in real } \\
\text { time, with a 24/7 alarm at the lower threshold. Temperature courses must } \\
\text { be regularly monitored, saved, and controlled } \\
\text { - Nitrogen storage time: approximately } 6 \text { months } \\
\text { - Prevention of burns and hypoxia accidents in handling the CAR-T cells in } \\
\text { and out of the nitrogen in the cryogenic recipients: ventilated premises, } \\
\text { with secure access reserved to trained and retrained personnel, no access } \\
\text { alone to the cryogenic area, and an oculus in the door so that any incident } \\
\text { can be detected from the outside. Oxygen levels at the floor are recorded in } \\
\text { real time and displayed with visual and sound alarms at the hospital } \\
\text { security station. The nitrogen storage symbol is displayed. First-aid } \\
\text { procedures are set out, with pictograms inside and outside the premises } \\
\text { - Protection of the staff: use of PPE to prevent burning via nitrogen contact } \\
\text { (gloves with sleeves up to the elbow, protective glasses, a lab coat, and } \\
\text { boots). Follow institutional standard operating procedures for liquid } \\
\text { nitrogen handling } \\
\text { Organization: stand-by duty rotation implemented for nights, weekends, } \\
\text { and holidays to enable intervention in case of any malfunction outside of } \\
\text { pharmacy opening times } \\
\text { Regular maintenance ensures good functioning of premises and tanks }\end{array}$ \\
\hline
\end{tabular}




\begin{tabular}{|c|c|}
\hline Workflow & Description of the process \\
\hline Thawing & $\begin{array}{l}\text { - After medicinal product recovery from the storage tank, a double check } \\
\text { (four-eyes principle) is again necessary to avoid any error in } \\
\text { administration: this includes a careful check of patient identity: name, birth } \\
\text { date, apheresis-ID, and batch number } \\
\text { - } \text { Check of concordance between the product and the haematologist's } \\
\text { prescription: patient identity, CAR-T denomination, administration date } \\
\text { - Check of the expiration date (even though CAR-T cells are stable over a } \\
\text { period of several months at temperatures below }-160{ }^{\circ} \mathrm{C} \text { ) } \\
\text { - } \text { Beginning of the thawing once the haematologist has given the green light } \\
\text { - } \quad \text { Thawing operations: } \\
\text { Performed by the pharmaceutical team on the day of administration, } \\
\text { with as short a time as possible; this requires coordinated planning with } \\
\text { the Haematology Department } \\
\text { Conducted on the pharmacy premises (or in the cell processing facility } \\
\text { if subcontracted), after double-wrapping the bag of CAR-T cells in a } \\
\text { protective plastic bag in a clean room, in a dedicated } 37 \pm 2{ }^{\circ} \mathrm{C} \text { water bath } \\
\text { until all ice crystals have melted in the bag. Depending on local } \\
\text { organization, a dry thaw method may also be used } \\
\text { Recommendation: double-wrap the bag in a watertight plastic bag for } \\
\text { thawing, to protect the bag of CAR-T cells and observe and control any } \\
\text { solution leakage due to accidental piercing of the original bag that may } \\
\text { have been overlooked at reception } \\
\text { After thawing, the CAR-T cells are stable at room temperature for } \\
\text { approximately } 30 \text { to } 90 \text { min, depending on the manufacturer (please refer } \\
\text { to the SmPC and the manufacturer's instructions) } \\
\text { - Usually, no processing step (wash, spin down, etc.) is required or allowed } \\
\text { - Commercial products should not be sampled }\end{array}$ \\
\hline & $\begin{array}{l}\text { - In case of CAR-T cells requiring processing before dispensation, injection } \\
\text { preparation in a pressurized preparation room with vertical laminar airflow } \\
\text { with no air recycling is necessary to prevent the risk of microbiological } \\
\text { contamination of the product and to minimize risks to personnel and the } \\
\text { environment }\end{array}$ \\
\hline $\begin{array}{l}\text { Transport } \\
\text { to the } \\
\text { Haematology } \\
\text { departmen }\end{array}$ & $\begin{array}{l}\text { The interval between thawing and administration is } 30 \text { to } 90 \text { min, } \\
\text { depending on the manufacturer, requiring precise timing, including } \\
\text { transport of the cells from the pharmacy to the department in a dedicated } \\
\text { and clearly identified container at room temperature } \\
\text { Warning: it is especially important to adhere to the manufacturer's } \\
\text { recommended interval as it seems to be a question of the presence of } \\
\text { dimethyl sulfoxide (DMSO), a cryopreservation agent that impairs cell } \\
\text { quality and viability at room temperature, in the CAR-T cell medium (Li } \\
\text { et al. 2019) } \\
\text { - In most cases, due to the short lifespan of CAR-T cells after thawing and } \\
\text { the risk of patient death in case of failure to administer, transport by the } \\
\text { pharmacist or a member of the pharmacy staff is recommended }\end{array}$ \\
\hline $\begin{array}{l}\text { Dispensing in } \\
\text { the } \\
\text { Haematology } \\
\text { Departmen }\end{array}$ & $\begin{array}{l}\text { Dispensation under a ready-to-administer form from the pharmacy, } \\
\text { preferably to the nurse who will be in charge of injection in the } \\
\text { Haematology Department. Recording the dispensation time } \\
\text { - Check by the pharmacist that the nurse has all the specific administration } \\
\text { devices, notably including a non-leukodepleting in-line filter } \\
\text { - All material that has been in contact with the CAR-T cell product (solid and } \\
\text { liquid waste) should be handled and disposed of as potentially infectious } \\
\text { waste and genetically modified organisms (GMOs) in accordance with local } \\
\text { biosafety guidelines and local and national regulations }\end{array}$ \\
\hline
\end{tabular}




\section{Administration}

Five to seven days ahead of CAR-T cell injection, lymphodepleting chemotherapy is started (Maus and June 2016). It is recommended to await reception and conformity checking of the CAR-T ATMP to avoid unnecessarily reducing patient lymphocyte levels in cases where nonconformity prevents administration.

CAR-T cell administration is scheduled by the haematology department in coordination with the pharmacy team and the Cell Processing Facility to allow for completion of the circuit under optimal conditions without delay of administration. Patient information and consent for the entire CAR-T process, including CAR-T cell infusion, is provided in advance by haematologists.

The cells are delivered intravenously at a $10-20 \mathrm{~mL} / \mathrm{min}$ infusion rate (gravity flow) without prewarming through a peripheral or central catheter. A nonleukodepleting in-line filter is used.

At some centres, the pharmacist is present at the bedside to respond to any request by the nurse, such as for an extra device. Even if not physically present, the pharmacist must remain quickly available upon request.

The hospital stay is approximately 2 weeks but longer in cases of major adverse events, such as cytokine release syndrome (CRS) or neurotoxicity, which may require transfer to the intensive care unit. Another important responsibility that lays with the hospital pharmacy is to ensure that two doses of tocilizumab (anti-IL-6R antibody) are immediately available for each treated patient as per SmPC.

\section{Patients Treated with CAR-T Cells: New Missions for the Hospital Pharmacist}

The steps along the CAR-T pathway highlight the role of the hospital pharmacist in this therapeutic innovation.

In the future, the increasing number and variety of ATMPs may require significant changes in pharmacy organization, notably in terms of premises and equipment (e.g., nitrogen tanks and vertical laminar airflow hoods) for proper and safe handling of the various types of ATMPs: somatic cell therapy medicinal products, gene therapy medicinal products (including CAR-T cells), and other categories of ATMPs, such as acellular gene therapy medicinal products, tissue engineering products, and combined medicinal products.

\section{Key Points}

- High medicinal standards of cell therapy products supervised by hospital pharmacists.

- Cryopreservation: a strictly regulated working environment that ensures safety of the products and requires implementation of stringent measures to protect the physical safety of involved staff. 
- High technical requirements, including $24 / 7$ monitoring of the cell storage site.

- Patient pathway: plan lymphodepletion chemotherapy after reception of CAR-T cells.

- Statement in the reception document regarding whether a back-up bag is available.

- Overall, the process is conducted within different facilities and requires good communication skills and a multidisciplinary approach.

\section{References}

Commission Directive 2009/120/EC of 14 September 2009 amending Directive 2001/83/CE of the European Parliament and of the Council on the Community code relating to medicinal products for human use as regards Advanced Therapy Medicinal Products (text with EEA relevance).

June CH, O'Connor RS, Kawalekar OU, Ghassemi S, Milone MC. CAR-T cell immunotherapy for human cancer. Science. 2018;359(6382):1361-5. https://doi.org/10.1126/science.aar6711.

Li R, Johnson R, Yu G, McKenna DH, Hubel A. Preservation of cell-based immunotherapies for clinical trials. Cytotherapy. 2019;21(9):943-57. Epub 2019 Aug 12. PMID: 31416704; PMCID: PMC6746578. https://doi.org/10.1016/j.jcyt.2019.07.004.

Maus MV, June $\mathrm{CH}$. Making better chimeric antigen receptors for adoptive T-cell therapy. Clin Cancer Res. 2016;22(8):1875-84. https://doi.org/10.1158/1078-0432.CCR-15-1433.

Pinturaud M, Vasseur M, Odou P. Role of the hospital pharmacist in the management of a category of advanced therapy medicinal product: chimeric antigen receptor T-cells. Bull Cancer. 2018;105:S205-13.

Regulation (EC) $N^{\circ} 1394 / 2007$ of the European Parliament and of the Council of 13 November 2007 on Advanced Therapy Medicinal Products and amending Directive 2001/83/EC and Regulation (EC) $n^{\circ} 726 / 2004$ (text with EEA relevance), vol 324, 2007. http://data.europa.eu/ eli/reg/2007/1394/oj/fra 
Open Access This chapter is licensed under the terms of the Creative Commons Attribution 4.0 International License (http://creativecommons.org/licenses/by/4.0/), which permits use, sharing, adaptation, distribution and reproduction in any medium or format, as long as you give appropriate credit to the original author(s) and the source, provide a link to the Creative Commons license and indicate if changes were made.

The images or other third party material in this chapter are included in the chapter's Creative Commons license, unless indicated otherwise in a credit line to the material. If material is not included in the chapter's Creative Commons license and your intended use is not permitted by statutory regulation or exceeds the permitted use, you will need to obtain permission directly from the copyright holder.

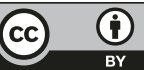

